\title{
Further Thoughts on Religion and Modernity
}

\author{
Peter L. Berger
}

Published online: 23 May 2012

(C) Springer Science+Business Media, LLC 2012

In recent decades there has developed a veritable cottage industry of commentary, criticism and reiteration of so-called secularization theory. I will not delve here into the details of what has been a storm in the teapot of the sociology of religion. Let me just restate what, when all is said and done, is the basic proposition of the theory-namely, that modernity necessarily brings about a decline of religion. I think that this proposition has been empirically falsified. It may be useful to summarize the steps which led me to this conclusion - not because my trajectory is unusual, but precisely because it is not unusual at all: Most observers have come to the same conclusion.

In my early years of my career I took the secularization proposition to be evidently correct, because just about everyone else in the field did so and because it seemed a coherent explanation of the religious scene. I resorted to this view in my early publications, including the one that made me known as a sociologist of religion, The Sacred Canopy (1967). My subsequent change of mind in this matter occurred gradually, and it had nothing to do with any theological reconsiderations of my own (my own religious position, that of a theologically liberal Lutheranism, has not changed since my youth). The change was caused by a number of experiences and reflections about these, happening sometime during the 1970s: Intensifying contacts with what was then called the Third World, first in Latin America, then in Africa and Asia-regions steeped in pervasive religiosity. First encounters with Evangelical Protestantism in the United States and its role in the unfolding culture wars, which sharply showed up the difference with the

\section{P. L. Berger $(\square)$}

CURA,

10 Lenox Street,

Brookline, MA 02246, USA

e-mail: plberger@bu.edu place of religion in Europe. The counterculture on both sides of the Atlantic, with its distinctively spiritual flavor. By the late 1980s I felt reasonably sure that the empirical evidence about religion in the contemporary world did not support secularization theory. I most noisily ratified this opinion in the introduction of a book I edited, The Desecularization of the World (1999). I was not alone in this. By then most scholars in the field had reached the same conclusion. It had become clear that most of the world was intensely religious. There were two exceptions to this generalization - one geographical, western and central Europe - the other sociological, an international secular intelligentsia. These exceptions had to be explained, but that is not my topic here.

How was secularization theory wrong? Basically, it was a very Eurocentric enterprise, an extrapolation from the European situation. Theories are the products of intellectuals, for historical reasons a very secularized class: Members of any class typically only talk to each other and thus reinforce their beliefs. Intellectuals think of themselves as children of the Enlightenment: For many of them, I suppose, secularization theory was wishful thinking. But for others (including myself-and, ironically, quite a few theologians) it was a matter of bravely facing up to what seemed to be facts. In retrospect, I think that we made a category mistake: We confused secularization with pluralization, secularity with plurality. It turns out that modernity does not necessarily produce a decline of religion; it does necessarily produce a deepening process of pluralization - a historically unprecedented situation in which more and more people live amid competing beliefs, values and lifestyles. This situation has profound effects on religion, to which I will shortly return, but these are different from the effects of secularization.

Thomas Kuhn, in his The Structure of Scientific Revolutions (1978), has given us a blow by blow account of what happens to scientific paradigms when they are challenged 
by empirical data. They are not given up right away, by those who have worked with them for years and are naturally attached to them. There are various attempts to modify them, here and there. When all these attempts fail to account for the data, paradigms will finally collapse. Only then does a new paradigm come about, new questions have to be asked and new avenues of research open up. Secularization theory is such a paradigm. I think an opening shot at the paradigm was fired by David Martin, in the revisions of his A General Theory of Secularization (1978), as he showed that there were significant differences even between European countries due to different historical developments. There have been a number of modifications devised to save the paradigm. One was based on the commonsense notion that the exception proves the rule: America may be an exception to secularization, but the general rule that modernity equals secularity still holds. That defensive maneuver was decisively shot out of the water by Grace Davie, who showed that Europe, not America, was the important exception (Europe: The Exceptional Case, 2002). Another modification was what I would call the "last gasp" theory of religion: Secularization is the inexorable wave of the future, but there are some residual resistances, which will eventually crumble. To deal with that one, let me suggest that one look at just the two most explosive religious movements in the contemporary world - the passionate resurgence of Islam, which encompasses the entire Muslim world from North Africa to Indonesia, as well as the Muslim diaspora in the west - and the huge expansion of Pentecostal or charismatic Christianity, according to survey data now numbering around 600 million adherents. Some last gasps!

But it is time now to discuss my further and very recent thoughts on religion in the modern world. These do not constitute a retraction of my view that secularization theory is empirically untenable (as has been amiably suggested by Steve Bruce, a very able defender of the theory). But they do amount to a new perspective on where the theory had it right after all. As often happens when one gets a new idea, it seems obvious and one is surprised that one had not thought of it before. I think that I held the misleading notion of some sort of unified consciousness, religious or secular. I had overlooked the (in retrospect obvious) possibility that an individual may be both religious and secular, in discrete compartments (what Alfred Schutz called "relevance structures") of the mind. Let me evoke two stereotypes: There is a Swedish professor of sociology, who is calmly convinced that all religion is an illusion, to the point where he can afford to be patronizingly tolerant of the few religious people who may cross his path. A few streets away from the professor's office there is a Pentecostal congregation of African asylum seekers, whose preacher performs miracles of healing every week. On closer investigation we may find that the professor regularly practices Tantric meditation, while the preacher operates with very secular rationality in his dealings with the Scandinavian welfare state.

Let me formulate a basic proposition: There is indeed a secular discourse resulting from modernity, but it can coexist with religious discourses that are not secular at all. What is more, this secular discourse has its roots in the science and technology which are the driving engine of modernity. Most people are neither scientists nor engineers, but the immense success of the discourse of science and technology in transforming the circumstances of human life, as well as the propagation of the same discourse through education, the media and the law, have given this secular discourse a taken-for-granted status. But this fact has not driven out religion, or even diminished its plausibility among very large numbers of people in most of the world.

I have arrived at the above proposition through reflection about some recent experiences, some of them due to projects at the Institute on Culture, Religion and World Affairs (CURA) at Boston University, a research center which I founded and with which I am still associated. For many years CURA has been engaged in research on global Pentecostalism, much of it in collaboration with David Martin, as a result of which I have become persuaded that Pentecostalism (along with the larger Evangelical community of which it is the most dynamic part) is a modernizing forcecontrary to the widespread view that it is a reactionary counter-modern movement. CURA has now been preparing two additional projects on the Evangelical community of theologically conservative Protestantism: One on a fascinating American development - the emergence of a growing group of sophisticated, self-confident Evangelical intellectuals - now moving into elite academia in a way curiously similar to what Jews did a few decades ago. There is even an increasingly vocal group of Pentecostal intellectuals, with their own association and journal. Let me just refer to an intriguing recent work by James Smith, Thinking in Tongues: Pentecostal Contributions to Christian Philosophy (2010). The other project is to deal with the robust supernaturalism of Christianity in the Global South, which has been mapped in ongoing publications by Philip Jenkins. But this is no longer an exotic phenomenon in backward regions: The demographic center of Christianity has shifted from Europe and North America to the Global South, and this new Christendom is strongly supernaturalist (and not only among Pentecostals). It is now spilling over into the more sedate churches of the Global North, partly through immigrants, also through missionaries seeking to evangelize the North. Thus not only do more people in Nigeria than in England attend Anglican services every week, but some of the most dynamic Anglican churches in England have Nigerian clergy (not to mention the fact that the Archbishop of York, the second highest individual in the hierarchy of the Church of England is an African). 
On a more experiential level, for the last three years I have been periodically teaching at Baylor University in Texas, a sort of Baptist Harvard in the midst of the Bible Belt. I have been impressed by its intellectual qualities, but also I have developed an ear for Evangelical discourse. Some of its phrases are instructive. There is a readiness to look for signals from God in occurrences that non-Evangelicals may take as coincidences. The phrase is "I think we are being told something here"- say, in a meeting where two seemingly unrelated statements by participants are taken as pointing to a specific course of action. Another phrase is "to pray over", as when people are uncertain which way they should go. Recently I was in conversation with an academic who moved from a prestigious secular university to a less prestigious Christian institution. When I asked him why he did this, he said that he was at first reluctant, but that he then "prayed over" the matter and became convinced that God wanted him to make the move. It is important to point out that many people who operate within this discourse are among the most economically successful in America, technologically up to date both in their personal lives and in their churches, and in some ways more rational (for example, in pursuing their political interests) than many secular academics. In other words, they successfully alternate between secular and religious definitions of reality.

In this connection let me refer to a very recent book by Tanya Luhrmann-When God Talks Back: Understanding the American Evangelical Experience with God (2012). Luhrmann is an anthropologist at Stanford University. She provides an excellent "thick description" of the world of members of the Vineyard Christian Fellowship, a charismatic movement with roots in the Californian counterculture of the 1960s. This side of Unitarianism (once described as a gathering of atheists who don't play golf and therefore are at a loss on Sunday morning), all Christians pray, in the belief that God hears them; many Evangelicals believe that, through inner voices and sometimes outward signs, God talks back. Luhrman carefully describes how they manage to find this plausible, despite doubts caused by the secular discourse in which they also operate. In one chapter she asks "Are they crazy?". She asserts that they are definitely not, after an elaborate comparison of their experience with that of schizophrenics. In the best anthropological tradition, Luhrmann maintains a balance between empathy and distance, and she emphasizes that in her anthropologist role she can make no statements about the ultimate truth or illusion of her subjects' experience. She apparently comes from a non-Evangelical, mainline Protestant background; she does not tell us to what extent she, like so many anthropologists, may have succumbed to the professional hazard of "going native". If so, she certainly succeeds in keeping the two discourses apart.

Jose Casanova, one of the best sociologists of religion around, has very usefully broken up the concept of secularization into three discrete meanings - the differentiation between religious and other institutions, the decline of religious belief and practice, and the privatization of religion. It is only recently that I was struck by something which, as an accredited propagator of the sociology of knowledge, I should have remembered much earlier in connection with Casanova's concept of differentiation: All institutions have correlates in consciousness. As religious institutions are differentiated from secular ones (as, for example, church from state, theology from science, and so on), the same differentiations must necessarily occur in consciousness. Consequently, a space opens up for secular discourse in the mind as well as in society. This process took many centuries, particularly in Judaeo-Christian civilization, before it emerged as modern secularity_Eric Voegelin, in his magisterial series of works titled Order and History, described the process as a movement from the "compactness" of the archaic cosmos to, precisely, the highly differentiated world of modernity. In this process "supernatural" reality is separated from the "natural", until a separate secular order becomes possible both in society and in consciousness. More recently, Charles Taylor has traced the same process in his bulky $A$ Secular Age (2007); he calls the secular discourse "an immanent frame".

However one describes the history leading to this, there now exists a powerful discourse which operates without recourse to religious definitions of reality. It relates to the latter differently in different parts of the world, but it is everywhere driven by modernization. I am not sure if this is the most felicitous phrase, but I would call it the default discourse: It is, as it were, the first call, made "naturally" even by religious individuals before they deliberately switch to their particular "supernatural" discourse. For example, if one of Luhrmann's charismatic Christians falls ill, he will spontaneously call a doctor; later on, or even at the same time, he may also ask a prayer group in his church to arrange a service of spiritual healing on his behalf. This plurality of what Alfred Schutz called "relevance structures" should not surprise us. It frequently occurs in everyday life. For example, I am moved by the beauty of a painting exhibited in an art gallery. Then I notice its price in the catalogue, and it occurs to me that buying it could be a good investment. In that moment I will have switched from an aesthetic to an economic relevance. A modern individual acquires the ability to juggle a plurality of relevances. In the book I wrote long ago with Brigitte Berger and Hansfried Kellner, The Homeless Mind: Modernization and Consciousness (1973), we called this trait "multirelationality" (not a great contribution to the language of Shakespeare and Milton). We did not think of religion at this point.

If secularization theory, at least in its original version, is no longer tenable, what should replace it in the sociology of religion? I have for quite some time argued that the replacement should be a theory of pluralization. This is not the place to re-argue the main features of such a theory. It must 
embrace both the societal and the mental dimensions of the enormous fact that (short of a radically totalitarian order) it is very difficult under modern conditions to retain or restore a monopolistic worldview. In society, this means that the normal institutional form of religion is the voluntary association (no matter whether churches like this or grudgingly accept it). The American term "denomination" denotes this institutional type. In the mind, it means that religion, no longer taken for granted, becomes a matter of individual decision. Again, the American language has an apt term for this-"religious preference". But religious plurality is not only an American phenomenon (though, for well-known historical reasons, it has developed in a distinctive version here); the phenomenon has been amply documented in Europe and elsewhere. Put simply, modernity does not so much change the what of religious faith, but the how. Much can be said about all of this, as I have done before. Here I just want to propose a significant addendum to a theory of pluralization: A default secular discourse co-exists with a plurality of religious discourses, both in society and in consciousness.

This proposition may be interesting to sociologists of religion. Should it interest anyone else? I think it should. It has far-reaching practical, indeed political implications. Some years ago Shmuel Eisenstadt suggested that there were multiple modernities. The term is polemical; it attacks the notion that there is only one form of modernity, that of Europe and its overseas extensions. That notion was first challenged successfully in Japan after the Meiji Restoration, as that country went through a radical process of modernization while consciously avoiding westernization. Today the idea of alternative versions of modernity is of burning urgency in many parts of the world: What could be the shape of an Islamic modernity? That question has come to the fore with the Arab Spring, but for some time before that event it was urgently debated in Turkey, in Iran and Pakistan, and with regard to the integration of Muslim immigrants in
Europe. Only slightly less urgent have been related questions elsewhere: What is the relation between secular democracy and hindutva in India? Between democracy and halacha in Israel? Can the Russian Orthodox Church make an adjustment with a secular state similar to the one made by the Roman Catholic Church since the Second Vatican Council? How can religious freedom be accommodated within the "harmonious society" proclaimed by the regime in China? And, last not least, the current electoral season in the United States has clearly demonstrated that religion continues to be a central issue in the culture wars over the character of American modernity.

The Peace of Westphalia in 1648 produced a compromise which, at least for a while, ended the terrible wars of religion that had killed millions of people across Europe. The compromise was embodied in the formula cuius regio eius religio the ruler decides on the religion of the state, and those who don't like the decision will be allowed to leave. It was a territorial peace formula, certainly an improvement over the massacre or forced conversion of religious minorities. Similar solutions are more difficult under modern circumstances and, where tried at all, have typically been accompanied by horrendous atrocities, as for instance in the flight of Muslims out of India and of Hindus out of Pakistan in the wake of Partition. It seems to me that contemporary plurality requires a nonterritorial formula of peace. The peaceful co-existence of a secular discourse in the public sphere with a plurality of freely chosen religious discourses suggests what such a formula of peace may look like. It need not look like, say, a translation of the first amendment to the US constitution into Arabic or Chinese. What it might look like will be determined by ideas and events in one country after another.

Peter L. Berger Senior Editor of Society, is Senior Research Fellow, Institute on Culture, Religion, and World Affairs at Boston University. His most recent book is Adventures of an Accidental Sociologist: How to Explain the World Without Becoming a Bore (2011). 